\title{
Slipping Moral Messages through the Islamic Novel Kidung Volendam with Positive Parenting Support for $\mathbf{Z}$ Generation
}

\author{
W T A Putri ${ }^{1}$ \\ State Institute of Islamic Ponorogo, Ponorogo East Java Indonesia ${ }^{1}$ \\ \{wtriaanugrahputri@,iainponorogo.ac.id ${ }^{1}$ \}
}

\begin{abstract}
This study aims to determine the quality of delivery of moral messages inserted in Islamic novel Kidung Volendam supported by Positive Parenting. This novel is one of the media favored by the public, one of which is the $\mathrm{Z}$ generation. Indeed there is no definitive study of $\mathrm{Z}$ generation demographics, but there are differences in how to obtain information and technological developments, so it is easy to guess people who are included as the millennial generation. The millennial generation in this study is early adulthood. Based on the stages of psychosocial development, Erick Erickson classifies early adults in ego identity vs. role confusion. These periods include the age of reproduction, age of position establishment, age of emotional stress. Referring to this, support is needed to make them a stable person and able to determine the future direction. Frequent reading also influences his mindset. The novel that is currently on the rise is a novel called Kidung Volendam. This novel is one of the Islamic novels with a background in place and culture in Banyuwangi. Novels with a lot of moral messages including slip respect for parents, respect for partners, loyalty is worth reading by these early millennial adults. Nevertheless, the role of parents is also still very much needed for the development of the individual in this early adult. Proximity is needed. Positive Parenting offers good support that parents can choose to accompany their children who are experiencing a transition from adolescence to the recent development. Approaching sons or daughters by reviewing the contents of the novel Kidung Volendam is expected to be able to provide opportunities for the adolescent to be able to determine decisions that are not only rational but also promote religion and respect for parents.
\end{abstract}

Keywords: Kidung Volendam; Positive Parenting; Early adulthood

\section{Introduction}

Teenagers are individuals who are aged 12 to 21 years. At this time individuals' ability to gain knowledge is at its maximum stage [1]. This condition is reflected in adolescents who are able to choose how to get knowledge from various mass media. There are teenagers who like to get information through online media and frequently also get information from print media, such as school textbooks, novels, magazines and so forth. Thus, if examined, a lot of information content is suitable for adolescents. 
This individual ability is followed by good reasoning ability. This matter will give a space for moral reasoning. In general, the task of development at this time is an ability to make decisions. The important thing to highlight is the ability to reason. The reasoning is an activity closely related to thinking but has a narrower scope. The scope is limited to the way of drawing conclusions from some of the things that have been thought of. The ability to reason is what will be able to direct individuals to be able to make decisions. This decision making will later determine moral direction.

Contrary to the conditions expected above, at this time there is a lot of juvenile delinquency. Juvenile delinquency can be as simple as ditching school to special delinquency such as drug use, sex outside of marriage and so on [2]. These juvenile delinquents often make distance the children from their parents.

The more protective of the child, the parents do not seem to give control over the child personally. For example, when there is a child who skips school then parents will worsen the atmosphere through questions wrapped in anger. For adolescence, reorganization of the frontal lobe circle occurs. This section aims to formulate decision making as part of a high-level thinking process [3].

In detail, there are some mistakes that parents often make in educating children including not listening to children, too busy, often using the word "must", too protective, criticizing the wrong way [4]. This will clearly disrupt the development of adolescents in various aspects that some parents may not realize.

When talking with teenagers, the current cognitive condition provides an opportunity to be able to anticipate various kinds of information that will be needed for problem-solving [5]. The proximity between parents and children who tend to be distant is added to the low learning capacity of adolescents in terms of reading literacy. Why are these two things related? Adolescence is a time of peak capacity in acquiring and using knowledge [6]. As the old saying goes that books are windows to the world, "reading" is a tool used to enter the vastness of the world. So what if teens don't have a high interest in reading? Then how much knowledge is used as consideration for solving problems in everyday life? This is indicated by the results of research conducted by PISA which concluded that from 70 countries the adolescents' interest in reading is relatively low. Indonesia ranks at 62 [7].

Even so, it does not mean that Indonesia has no interest in reading at all. The news reported by Togamas also provides good hope for teenagers ' interest in reading. Togamas concluded that the novel is a reading that is preferred by adolescents compared to other genre books [8]. Based on his survey, Togamas obtained interview data that the novel has a more exciting story. These results are supported by the number of novels sold around 700 to 800 books. The total sales of 1000 books include all types of books.

Thus, this study aims to offer ideas of anticipating juvenile delinquency. The positive parenting study is used as the right approach from parents to adolescents. This approach is to make sure that parents no longer make mistakes in educating adolescents. To accommodate the adolescents' ability in thinking at a higher level, the novel entitled Song of Volendam is used to provide knowledge and many moral messages. In the end, this study aims to deliver teens problem-solving strategies with knowledge and moral messages by not leaving good communication with family. 


\section{Literature Review}

Parenting is broadly interpreted as a parenting pattern for children. Positive parenting refers to warm parenting ways to the child in the form of support, placing the child in the right situation and reason, and giving full of appreciation to the child [9].

Supporting children who are the primary focus of psycho parenting has several principles. The principles are as follows: first, the main target of the child is a sense of ownership and significant effects, second, all child behavior must be goal-oriented, third, the child who behaves badly is a discouraged child [10].

Particularly with the first principle, children must have a role in a family. Many parents immediately give assistance to children when they feel difficulties. In fact, please note that children also want a feeling of belonging to roles in a family. With the ability to play a role and the ability to solve their own difficulties, children become more resilient individuals. Having this role will support to connect with families. The environment around adolescents is what influences moral reasoning [11].

In the second principle, all actions were taken by a child or teenager actually have a purpose. Parents should respond to this study. In a sense, bad behavior in children is a consequence of parents or adults who do not give control to adolescents over themselves. Nevertheless, the unique thinking of adolescents still requires self-control. A form of bad behavior or juvenile delinquency is a way for adolescents to be able to have control over themselves.

In the third principle, the child's behavior is not solely because the child really wants it. The cause of bad behavior is what should be explored further. Some things emphasized by Mac Cready about this principle are: children who behave badly are not naughty children, children who behave badly do not mean disobedient children, children who behave badly are only children who are discouraged. The cause of discouragement is believed to be an indicator that the child does not have control for himself.

Some ways of a realization of positive parenting are as follows: the first is by giving the opportunity to adolescents to get the feeling, the second being a good listener of all the stories of adolescent experiences [12]. Cognitive is also an aspect that develops significantly in adolescents. Teenagers try to check the values obtained from parents [5]. This is an opportunity for parents to be better able to know the extent to which teenagers check the rules of parents.

\section{Result and Discussion}

\section{Novel Kidung Volendam and Positive Parenting}

The novel is described in such detail to makes it easier for readers to imagine the physical and environmental character as expected by Halimah Munawir. The experience of this fictional character can be a moral message. Surely, the teenagers who really like reading novels can absorb it.

In this study, parents are able to recommend this novel as reading material for their sons and daughters who are in their middle and late teens. There are so many novel books that are arranged in book stores, so it is not wrong if parents recommend novels with Islamic nuances.

Not only limited to moral messages, but this novel also presents a number of local and non-local cultures. Generation $\mathrm{Z}$ is able to get information about the location of tourist attractions in several areas and environmental conditions. Likewise, with language, teenagers are able to make it a means to learn Dutch or local languages (Javanese). 
The writer of this novel highlights a causal relationship between children and parents. It is a supporting factor for positive parenting. For parents who do not know the concept of positive parenting, they will often complain. Complaints that have been studied are parents feel the burden and feel bothered and are able to spend a long time too [13]. Even so, for parents who really want to try with all their heart, the novel Kidung Volendam and positive parenting can be put together to be close to the child's personality.

The complexity of the problems in the novel can be used as an alternative discussion between parents and children about the norms of life. With a positive parenting approach, parents are given the means to talk more with their children and the study is not monotonous or too short. Indirectly, parents have conveyed their guidance and advice to children through small talk about this novel.

\section{Moral Messages in Novel Kidung Volendam}

Moral has several scopes, either individual, social, or religious moral messages [14]. The details are as follows: first, the scope of the individual consisting of a) loyalty shown by the character Dwight who is always faithfully waiting for Ambarwati to meet soon. Dwight's figure often chants longing songs. b) The next moral message is the big soul shown by Liza who still wants to accept her stepchildren, even though the relationship between David's mother (stepdaughter) was almost and her husband almost destroyed her marriage with Dwight. c) The next moral message: be careful in acting and keeping promises shown by Arief who never approached Ambarwati despite the love in her heart for making a promise with Dwight. d) Responsibilities: Ana who is willing to work hard to support her blind mother. e) Gracious: David and Ana, who must be strong in facing the fact that children are born with disabilities.

Second, moral messages in the social sphere include a) Affection: Liza who is not David's biological mother always receives him well. b) Loves to help: Ramlan is willing to help Dwight and his family to find the whereabouts of Ambarwati and her daughter. c) Respect to parents: David finally donates one eye to his mother (Ambar) who is blind. Third, the moral message in the religious sphere is: obeying God's commands: Dwight who in the end always does the prayer. There are so many moral messages that might not be included in the table above because of restrictions on certain things.

\section{Moral Study for Z Generation through Novel Kidung Volendamand Positive Parenting}

The concept of positive parenting in this study must be in accordance with the six main pillars. The author presents by adjusting the age of Generation Z. The reason, this generation is certainly different characters from previous generations. This difference has certainly been presented in the previous section. The main pillars that serve as benchmarks are partnership, $4 \mathrm{~B}$, agreement, understanding of negative emotions, positive language style, parenting without penalty[15].

In accordance with the first pillar, between parents and adolescents, there must be a partnership. This relationship is proven by being able to work together. In cooperation activities, it is necessary to have the same mission with each other in order to produce maximum results. Equating this perception is not something easy between parents and children. The way that parents can do is to spend a special time every day to communicate in one family. This communication is realized by chatting casually. Of course, this habit must be 
done continuously. The goal is that each family member feels uncomfortable if not spending time chatting in one family.

Perhaps most will argue that indeed every day has been communicating, but what needs to be realized is that communication becomes a secondary activity. The main activity is, for example, watching television accompanied by chatting about soap opera titles or films or talk shows. By communicating, it refers to carrying out these activities as the main activities, not interlude activities.

Parents can choose which room is used for casual chatting. The room used to adjust family comfort. The presenter observes a family that uses the dining room for a family chat [16]. Clearly, free chat between all children and their parents is more often done in the room not as a secondary activity, but indeed a major activity.

By communicating lightly in an intense manner, it will indirectly provide an opportunity for all family members to equalize their vision and mission in achieving something. It's like a meeting but with a relaxed situation. Like meetings, each family member has the right to speak. An opportunity to argue can possibly provide mental health for children. Mental health in question is about self-worth, satisfaction in carrying out roles in the environment (family), and having a good relationship with others (parents) [17].

This $\mathrm{Z}$ generation is a generation who is considered versatile because it often does DIY than to increase partnerships with parents, can be added to activities carried out together. Parents provide opportunities for children to be involved in jobs that are considered heavy. By giving confidence, children will feel confident.

In accordance with the second pillar, which is $4 \mathrm{~B}$ (stroking, talking, playing and thinking), it is actually the concept of closeness that needs to be emphasized. This second pillar can be done as in the first pillar. Activities can be added by inviting children to think. Thinking, in this case, is deep thinking or inclined to reasoning, for example giving children the opportunity to talk about their problems and giving critical questions about cause and effect.

If the child is considered a teenager, then caresses can be replaced with a pat on the back as a sign of parental support for children. This support is believed to be able to influence children's development at a later stage.

According to the third pillar, teenagers and parents make an agreement in applying the rules. Discipline is the main key. This activity is not only obeyed by children but also by both parents. This agreement can be done through activities to determine the hours outside the home. Every individual certainly wants to maintain his existence outside the home through association. Comfort in relationships often makes individuals forget about home. By applying it, each family member knows his obligation to be at home immediately. Although impressed rigid, but a relaxed but serious way of delivery is certainly able to make the atmosphere conducive and does not seem pushy.

Other possible activities are agreement in determining the schedule to clean the house. This scheduling indeed feels rigid and forced, but with the delivery of both parents to children politely and casually will open the way for children to understand a condition. To schedule, of course, the involvement of children is very necessary.

In accordance with the fourth pillar, the parents' understanding of children's negative emotions. Every individual is not a perfect figure. Always being a spear with two equally sharp ends, that is the picture of an individual, that is, having weaknesses and strengths. Anger is a form of negative emotion that actually must be owned by everyone. Nevertheless, it does not mean that an announcement without a balanced follow-up is considered as the right choice. Finding the cause of anger is the focal point in this pillar. 
When adolescents display negative emotions, no blame should be placed on the individual. What needs to be improved is his attitude and not blame the person. In accordance with the fifth pillar, a positive speaking style is needed when communicating. Often there is a negative style of speech when parents talk to children. A negative speaking style can make the gap between parents and children. Examples of negative speech styles are always prohibiting and mentioning the consequences of being too frontal. When parents say negative things, it will hinder the courage of children in dealing with the problem.

What parents need to do is to try to express their opinions but with a positive speaking style. Forbidding a teenager to go home late at night might be more acceptable if replaced with a dinner invitation. As parents, of course, also find it difficult to replace negative words into positive ones. Indirectly what the individual has conveyed illustrates what the individual has received. If you often say negative things, then most likely the individual often accepts negative things as well.

In accordance with the sixth pillar, i.e. caring for without punishing, parents should abolish the punishment if a teenager makes a mistake. As a reminder, teenagers have started to be in the stage of conventional moral reasoning, which is already familiar with the concept of morality.A generation $\mathrm{Z}$ teenager has found many ways to get knowledge about morality in various media. Parents must trust their children that punishment is a way of teaching for children with pre-conventional moral stages, while adolescents are at a conventional stage.

The learning model for Generation $\mathrm{Z}$ through novels and parenting is based on the six positive parenting pillars as described in the previous sub-chapter. To tuck in a moral message, parents firstly sort out the kind of adolescents' problems. This is in line with the concept of the Zone of Proximal Development which will provide knowledge in accordance with what has been known by students as a foothold.

When parents already know what problems children are facing, it will be easy for parents to give a picture of cause and effect as in the novel. It is intended that teenagers have mature considerations to determine decisions. Certainly not even a parent who wants negative consideration is obtained.

\section{Conclusions}

This paper concludes that the existence of moral messages can be conveyed to children as part of Generation Z. The moral messages obtained in the novel are numerous. The contents of the novel can be the subject of conversation by parents and children for applying positive parenting. Based on the six pillars of positive parenting, parents will find it easier to approach their growing children. A simple way to do this is to have a relaxed and intense conversation.

This study still has many shortcomings. The constructive suggestions and criticisms to improve the quality of this study are needed to provide the current educational treasure.

\section{References}

[1] C. E. Izard, J. Kagan, and R. B. Zajonc., Emotion, Cognition, and Behaviour. New York: Cambridge University Press, 1984.

[2] S. Sartono, "Pengukuran Sikap Masyarakat terhadap Kenakalan Remaja (Laporan Penelitian)," Depok, 1985.

[3] C. K. Sigelman and D. R. Shaffer., Life Span Human Development. California: Wadsworth Publishing, 1994.

[4] K. Sahabat, "Lima Kesalahan Orang Tua dalam Mendidik Remaja," 2019. . 
[5] Desmita, Psikologi Perkembangan. Bandung: Remaja Rosdakarya, 2008.

[6] C. Mussen, Kagan, and Desmita, "Psikologi Perkembangan.” p. 194, 2008.

[7] (blog) OECD, "Reading Performance (PISA)," 2015. .

[8] Togamas, "Dibanding Pengetahuan, Novel Lebih Diminati Remaja," 2015. .

[9] E. Hayes, Tantrum. Jakarta: Erlangga, 2003.

[10] A. MacCready, "What is Positive Parentig? Does it Work?," 2019. .

[11] S. K. Tarigan and A. R. Siregar, "Gambaran Penalaran Moral pada Remaja yang Tinggal di Daerah Konflik," Psikologia, vol. 8, no. 2, pp. 79-88, 2013.

[12] Blog Informasi anakku, "Positive Parenting," 2014. .

[13] Halimah, "Pengalaman Orang Tua dalam Mengasuh Remaja dengan Perilaku Kekerasan di Kota Depok," Depok, 2009.

[14] Sulistyorini, Menyiapkan Kesuksesan Anak Anda. 2007.

[15] H. M. Darta, Six Pillar of Positive Parenting. Jakarta: Cicero Publishing, 2011.

[16] Bapak C, "Komunikasi Keluarga.” 2019.

[17] N. S. Sukmadinata, Landasan Psikologi Proses Pendidikan. Bandung: Remaja Rosdakarya, 2007. 